\title{
Correlations between phytoplankton, organic detritus and carbon in North Sea waters during the Fladenground Experiment (FLEX' 76)
}

\author{
G. Gassmann ${ }^{1} \&$ M. Gillbricht ${ }^{2}$ \\ 1 Biologische Anstalt Helgoland (Meeresstation); D-2192 Helgoland, \\ 2 Biologische Anstalt Helgoland (Zentrale); Notkestraße 31, D-2000 Hamburg 52, \\ Federal Republic of Germany
}

\begin{abstract}
Quantitative analysis of phytoplankton, organic detritus and dissolved organic carbon was carried out, during the spring bloom, in a specific North Sea area $\left(58^{\circ} 55^{\prime} \mathrm{N}, \mathrm{O}^{\circ} 32^{\prime} \mathrm{E}\right)$ in the course of an international and multidisciplinary marine investigation (FLEX' 76). An attempt was made to correlate the fluctuations of these variables; the analysis, however, was complicated by massive water movements. A maximum of the phytoplankton bloom coincided with a maximum of organic detritus, while both variables turned out to be inversely correlated with the dissolved organic carbon content. The initial, high amount of dissolved organic carbon declined at a daily rate of ca. $13 \%$ during a period of non-interference by water movements. Two thirds of the dissolved organic carbon content are assumed to be transformed into particulate organic matter whilst the rest disappears through still unknown channels.
\end{abstract}

\section{INTRODUCTION}

The principal biological objective of the Fladenground Expedition (FLEX' 76) was to study the dynamics of the basic trophic levels of the marine food chain. One unsolved problem is the fate of the non-living particulate (detritus) and dissolved organic material. Biologists and chemists have been investigating this problem since the beginning of the century. Lohmann (1908) studied the significance of dead particulate organic matter (organic detritus) as a source of nutrition for particular animals (e.g. larvae of Spionidae). Pütter (1909) discovered great quantities of dissolved substances by means of an analytically wrong method (Raben, 1910) and considered these substances important for the survival of aquatic animals.

Many investigations have been carried out in this field but only a few relevant publications are considered here (for review see Wangersky, 1978). Surface-active organic compounds may form surface films in calm weather (slicks) inhabited by phytoplankton (Wandschneider, 1979). This system is destroyed by high winds, indicated by an increase of the surface tension (Hühnerfuß et al., 1977). The particulate matter in the sea then becomes enriched with the surface-active components of the dissolved organic material, thereby receiving a negative charge (Neihof \& Loeb, 1974). This pool of enriched particulate matter is diminished by the grazing activity of bacteria, for which it serves as a 'meadow' (ZoBell \& Anderson, 1936). Small amounts of organic 
material near the surface are destroyed by UV light (ZoBell, 1933), whilst a considerable portion may be taken up directly by the phytoplankton (Schreiber, 1927).

What is the origin of the soluble substances? According to commonly accepted opinion the greatest quantity is produced by phytoplankton (diatoms): under favourable growth conditions this may amount to $6 \%$ of the production (Fogg et al., 1965); during a decaying phase the amount may be much higher; a wide range of values has been obtained (Anderson \& Zeutschel, 1970; Choi, 1972). Consequently, there is a parallelism between phytoplankton and dissolved organic carbon (Duursma, 1963) (Fig. 6) with a time lag between the maxima (Duursma, 1965).

The situation is more complicated with respect to organic detritus. Phytoplankton is known to represent a small fraction, in the range of $10 \%$, of the particulate matter (seston) (Gillbricht, 1952). Organic detritus is produced in the open sea chiefly by planktonic organisms. In addition, dust, sand grains, pollen and other materials stem from terrestrial sources; in shallow waters along the coast, the sea bottom also yields large amounts of particles.

It is difficult to understand how, in spite of the long life time of dissolved organic carbon (Laane, 1980), such great quantities of dissolved substances can be 'decomposed' on the small surfaces of the particulate matter. Tsujita's (1953) comments are of interest in this respect; he observed an organic 'matrix' on the surface following a phytoplankton bloom. This phenomenon has been thoroughly investigated since the Sixties. Ramsey (1962) found slick formation coinciding with air bubbles in a convergence zone. Kalle (1968) discussed the transformation of surface-active dissolved organic carbon into 'aggregates' on air bubbles and on surfaces of particulate matter. During his experiments, Riley (1970) observed an equilibrium between aggregates and dissolved material. Kranck (1980) proposed that formation of organic matter by transformation of dissolved matter into particulate matter is induced by changes in the turbulence of the water this suggestion was based on observations made in an inlet. This information and additional evidence imply that transformation from dissolved to particulate matter not only takes place from time to time, but may also be highly significant with respect to the dynamics of the chemical and biological processes in the sea.

\section{MATERIAL AND METHODS}

During FLEX '76, samples were taken in water bottles at the central station $\left(58^{\circ}\right.$ $\left.55^{\prime} \mathrm{N}, \mathrm{O}^{\circ} 32^{\prime} \mathrm{E}\right)$ by R. V. "Meteor" to be investigated with respect to phytoplankton, particulate organic carbon (POC) and dissolved organic carbon (DOC). These measurements were made daily between 25 March and 5 June 1976 (phytoplankton: 29 May) with short interruptions and one break from 13-23 April. Mean values down to a depth of $30 \mathrm{~m}$ (normally: $5,10,20,30 \mathrm{~m}$ ) were calculated excluding the surface film and some obvious runaways (POC, DOC). Calculations were made over two differing periods of time in order to interpret the dynamics of POC and DOC (Table 1).

\section{Phytoplankton}

A volume of sea water $\left(240 \mathrm{~cm}^{3}\right)$, bottled directly after sampling, was preserved in Lugol solution and stored in this form. To facilitate the counting of phytoplankton, most 
Table 1. Observation periods, number of observation days and number of vertical series used for this investigation

\begin{tabular}{|cccc|}
\hline $\begin{array}{c}\text { Observation } \\
\text { period }\end{array}$ & Components & $\begin{array}{c}\text { Days of } \\
\text { observation }\end{array}$ & $\begin{array}{c}\text { Vertical } \\
\text { series }\end{array}$ \\
\hline March 25 & phytoplankton & 47 & 158 \\
to June 5 & POC & 55 & 192 \\
& DOC & 54 & 190 \\
April 24 & phytoplankton & 12 & 41 \\
to May 7 & POC & 13 & 43 \\
& DOC & 12 & 42 \\
\hline
\end{tabular}

of the clear water was siphoned off the sample in the laboratory, using a cylindrical separating funnel. A rough count of the samples was then quickly made with the aid of an inverted microscope (Gillbricht, 1959), employing knowledge gained by practical experience and theoretical considerations (Gillbricht, 1962). The highest volume counted for large forms (Ceratium) was ca. $10 \mathrm{~cm}^{3}$ and for small ones (naked flagellates) ca. $0.5 \mathrm{~cm}^{3}$, reduced in the case of large populations.

The number of individuals was then transformed into $\mu \mathrm{g} \mathrm{C} \cdot \mathrm{dm}^{-3}$ via plasma volume, using the method given by Lohmann (1908). The conversion factors of the different species were taken from Lohmann (1908) and Hagmeier (pers. comm.) after adaption to the special situation. However, some inaccuracy of the counting and

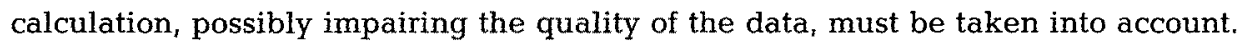

\section{Particulate and dissolved organic carbon}

The methods for determining POC and DOC followed the wet oxidation procedure of Menzel \& Vaccaro (1964) using a commercial instrument (Oceanography International, Texas). The latter consists of a glass ampoule sealing device, a high pressure autoclave and an ampoule breaking and stripping device. It also includes a nondispersive infrared gas analyser, an electronic integrator and a printer. This procedure is especially seaworthy since ampoule sealing on board preserves the samples until analysis. The disadvantages of the wet oxidation method, deriving from the oxidant $\left(\mathrm{K}_{2} \mathrm{~S}_{2} \mathrm{O}_{8}\right)$ used here (Wangersky, 1981), have been accepted because 9000 samples had to be processed during this investigation.

For particulate carbon analysis, $500 \mathrm{~cm}^{3}$ sea water were filtered through precombusted $\left(450^{\circ} \mathrm{C}, 2 \mathrm{~h}\right)$ glass fibre filters (Whatman $\mathrm{GF} / \mathrm{C}$, pore size $<1.2 \mu \mathrm{m}$ ) under a constant vacuum $(500 \mathrm{mbar})$. In this way, the definition is given of the difference between 'particulate' and 'dissolved'. The filters were placed in precombusted $\left(500^{\circ} \mathrm{C}\right.$, $8 \mathrm{~h}$ ) glass ampoules (Fiolax, Münnerstadt), containing $200 \mathrm{mg}$ oxidant and $0.6 \mathrm{~cm}^{3}$ of $\mathrm{H}_{3} \mathrm{PO}_{4}(3 \%)$. After addition of $10 \mathrm{~cm}^{3}$ of tri-distilled water and stripping the residual $\mathrm{CO}_{2}$, the ampoules were sealed under purified oxygen. For dissolved organic carbon analysis, a $10 \mathrm{~cm}^{3}$ aliquot from $500 \mathrm{~cm}^{3}$ filtered sea water was handled in the same way. Fifteen samples, 5 blanks (distilled water, reagents and filter) were processed in the same manner. 
Final analysis was performed three months after the expeditions. The autoclaved ampoules $\left(130^{\circ} \mathrm{C}, 12 \mathrm{~h}\right)$ were analysed for $\mathrm{CO}_{2}$. The results were quantified by comparision with a calibration curve established by oxidizing known quantities of carbon originating from glucose and potassium phthalate.

Wet oxidation may be incomplete but normally only to a small degree (Wangersky, 1981). Possibly there is a great difference in this special case (Brockmann et al., 1982), but wet oxidation has the advantage of producing good results in respect to the biologically essential material.

\section{RESULTS}

The development of the phytoplankton, the carbon content of the detritus, the dissolved organic carbon and the sum of detritus + dissolved organic carbon are given in Figure 1 (mean values for 10 days). Detritus is defined as particulate organic carbon minus phytoplankton carbon (Lenz, 1977); in this way small quantities of zooplankton and bacteria are included. The phytoplankton stock is hardly of any account compared with the amount of detritus and dissolved matter. The amount of detritus runs parallel with the amount of phytoplankton as expected, but the development of dissolved material is highly abnormal: when compared with the phytoplankton, a contrary trend can be seen. Furthermore, the strong increase in the quantity of detritus, which thus exceeds the DOC, cannot be explained as a product of local phytoplankton production. The same situation was observed later on concerning the dissolved matter and the sum of the detritus + DOC.

An analysis of these observations is complicated by the fact that the actual chemical and biological dynamics are masked by water exchange processes. This effect may be

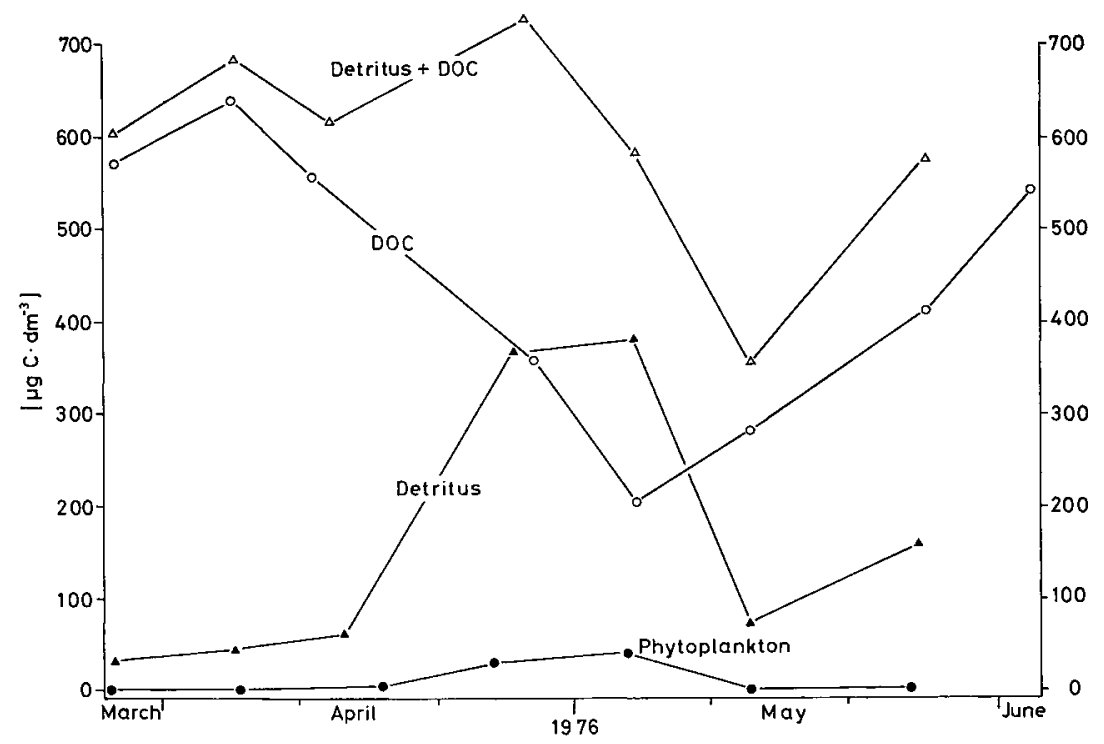

Fig. 1. FLEX '76: central station, mean values for ten days, carbon content: phytoplankton; detritus; dissolved organic carbon; detritus + dissolved C 


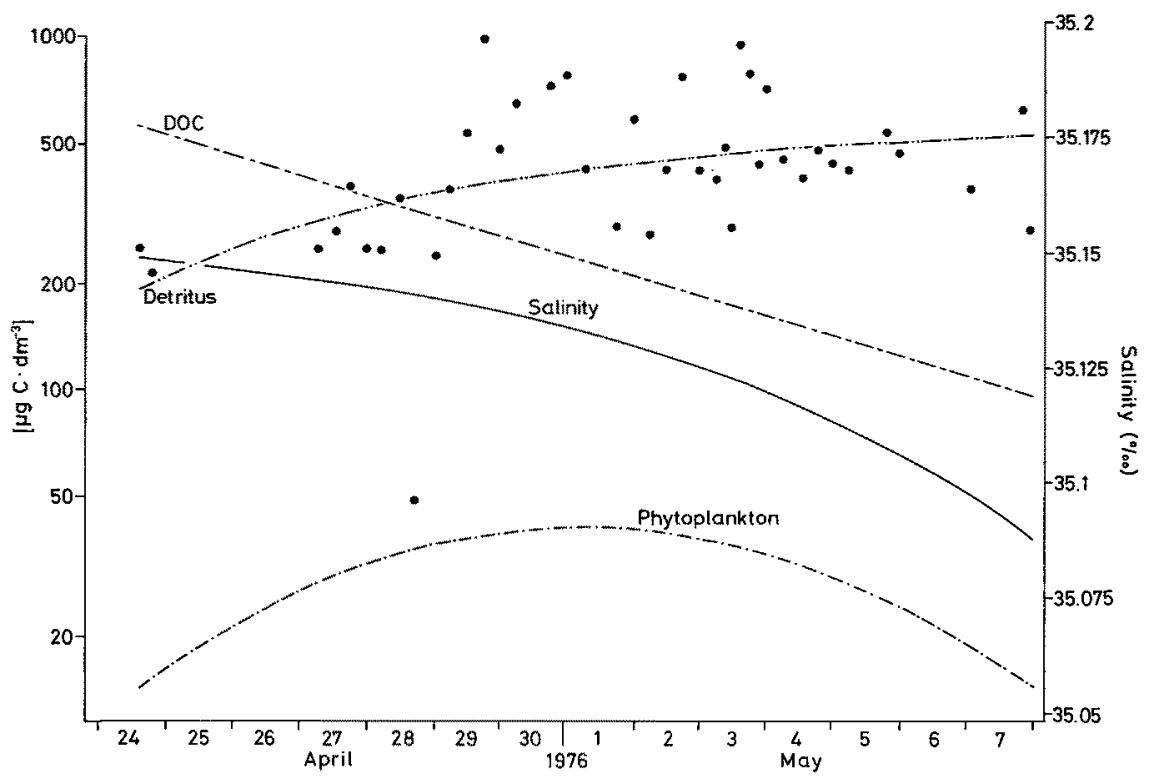

Fig. 2. FLEX '76: central station, smoothed curves (calculated by means of optimal broken exponents): salinity ( $N=43, \mathrm{r}=-0.376, \alpha<0.025)$; carbon contents (logarithmic scale): phytoplankton $(\mathrm{N}=41, \mathrm{R}=0.465, \alpha<0.025)$; dissolved material $(\mathrm{N}=42, \mathrm{r}=0.779, \alpha<<0.001)$; detritus $(\mathrm{N}=41, \mathrm{r}=-0.431, \alpha<0.01)$

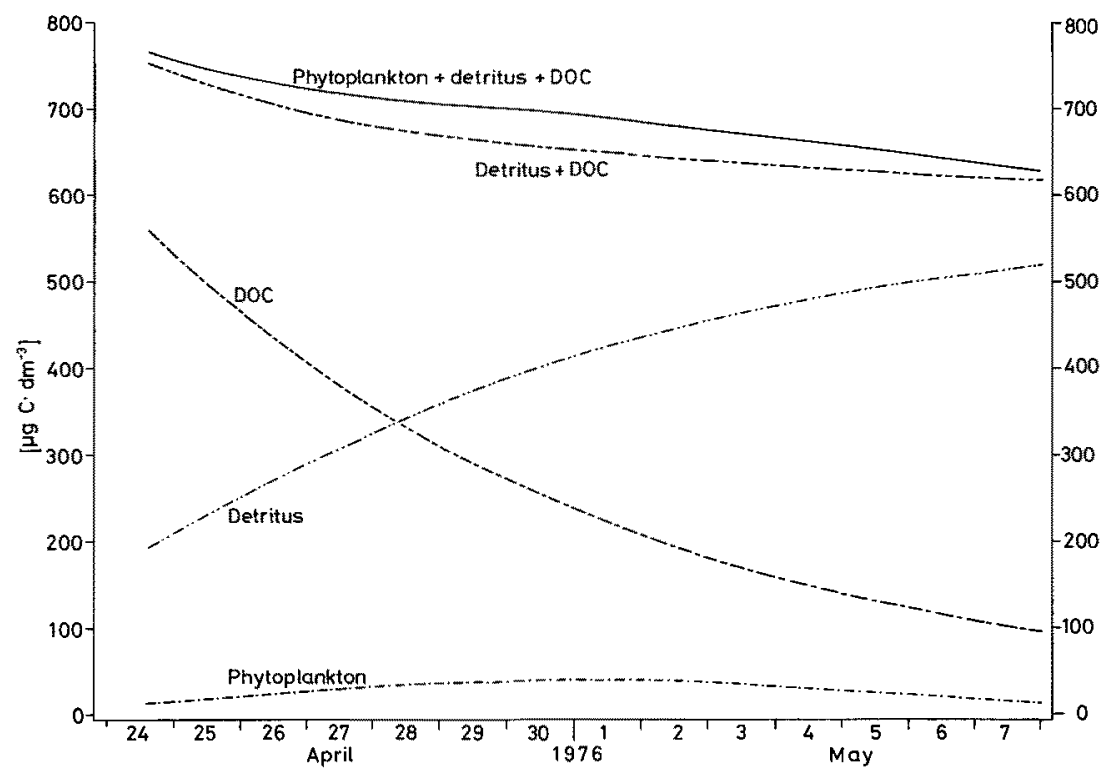

Fig. 3. FLEX '76: central station, carbon content in a numerical scale: phytoplankton; dissolved C; detritus; detritus + dissolved $C_{\text {i }}$ phytoplankton + detritus + dissolved $\mathrm{C}$ 


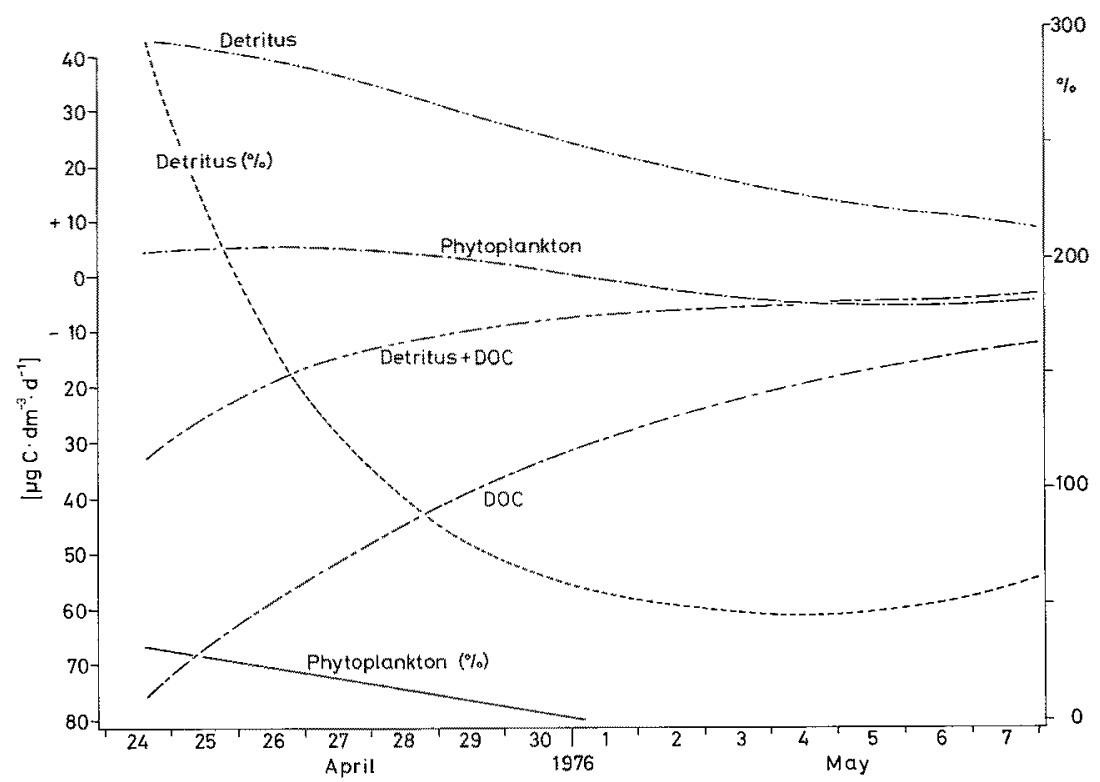

Fig. 4. FLEX '76: central station, changes per day (first derivative) given in $\mu \mathrm{g} \mathrm{C} \cdot \mathrm{dm}^{-3} \cdot \mathrm{d}^{-1}$ or as a percentage of the phytoplankton stock: phytoplankton; dissolved $\mathrm{C}_{i}$ detritus; detritus + dissolved $\mathrm{C}_{i}$ phytoplankton (\%); detritus (\%)

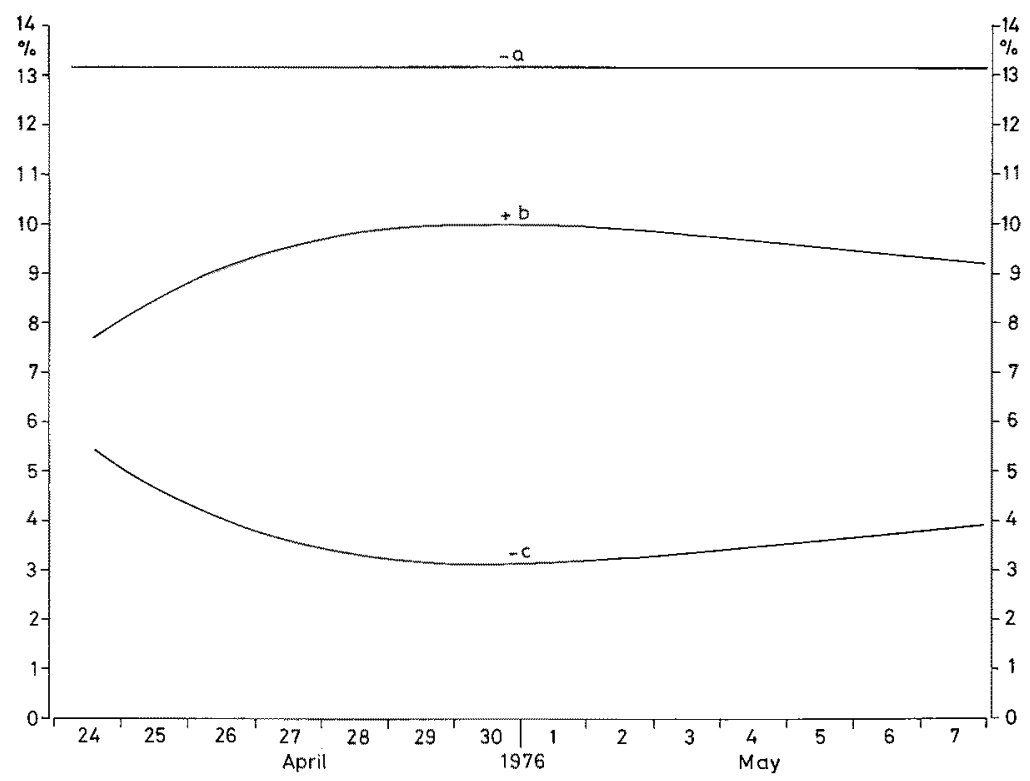

Fig. 5. FLEX '76: central station, changes per day expressed in \% of the dissolved organic carbon: $-\mathrm{a}=$ decrease of the dissolved material $_{i}+\mathrm{b}=$ increase of the detritus; $-\mathrm{c}=\operatorname{sum}$ of $(-\mathrm{a}+\mathrm{b})$ 
different for several components. The fast growing phytoplankton is within a short period of time in equilibrium with the environment and therefore hardly influenced by the different history of different water bodies. In this way, the respective boundaries are extinguished (Gillbricht, 1977). The situation is more complicated with respect to detritus and dissolved substances. It is, therefore, necessary to eliminate as much as possible the influence of different water exchange processes. From a theoretical point of view this is possible by calculating the water movements, bearing in mind the threedimensional distribution of the components in question. A practical solution of this problem is possible by explaining all water exchange processes by variations of the (relative) conservative salinity and eliminating this effect by corrections (Gillbricht, 1977). The next step in this procedure is to describe the respective components as functions of time and salinity and to find a period without any significant influence of salinity. The result of this method is not satisfying, indicating some water exchange in spite of the exclusion of the effects coupled with salinity. The increase of the sum of detritus + dissolved matter is too great compared with the phytoplankton stock, and, moreover, the period in question includes the break. This result gives an indication of the transformation of the dissolved matter into particulate matter. The results presented in Figure 2 are obtained by excluding the beginning and end of the investigation period and studying only the middle period comprising two weeks. The effect of salinity variation during this period was assumed to be weak. The other smoothed curves are calculated by means of logarithms. This method of data evaluation is better from a theoretical point of view but gives poorer results than a numerical system. Dissolved matter declines logarithmically, and detritus increases with a decreasing tendency.

The situation can be sufficiently demonstrated by using a numerical scale, indicating the small proportion of phytoplankton and the permanent decrease of dissolved material and of the combined sum of detritus + dissolved matter in spite of the phytoplankton bloom (Fig. 3). The daily changes of the different components are given in Figure 4, indicating the strong decrease of the dissolved carbon and the smaller increase of the detritus. Additionally, the daily increase of detritus and of phytoplankton, measured as a percentage of the phytoplankton stock, becomes evident.

It is interesting to note the daily changes of the dead organic material in relation (\%) to the dissolved organic carbon. As can be seen in Figure 5, the relative decrease of the dissolved material is constant for this period (Fig. 2) with a value in the range of $13 \%$, whilst the increase of detritus is ca. two thirds of this amount, possibly built up by particularisation of the dissolved matter. Evidently, the rest (ca. one third) of this fraction is lost through other channels.

\section{DISCUSSION}

Generally speaking, chemical and biological processes in the sea cannot be measured directly, but must be deduced indirectly by comparing the changing states. The distortion of the results in this study, caused by different types of water movements, mirrors the difficulties encountered when trying to assess these processes. Therefore, the only reasonable method of measuring complex dynamic processes in the sea is to compare the data obtained from studies of sea water samples in jars and containers of different volumes. It is obvious that findings obtained under such semi-natural conditions must be verified with respect to the true situation occurring in the open sea. 
Further, it is necessary to include measurements made under abnormal conditions, in order to gain additional insight into the dynamic processes which take place in the marine environment. In the special case reported here, a surprisingly large amount of dissolved organic carbon was measured at the beginning of the investigation with a pronounced minimum during the phytoplankton maximum (Fig. 1). This is in contrast to other findings. The 'normal' situation can be seen for instance every year in the Helgoland region (Fig. 6). Phytoplankton and organic carbon (in the first range, dissol-

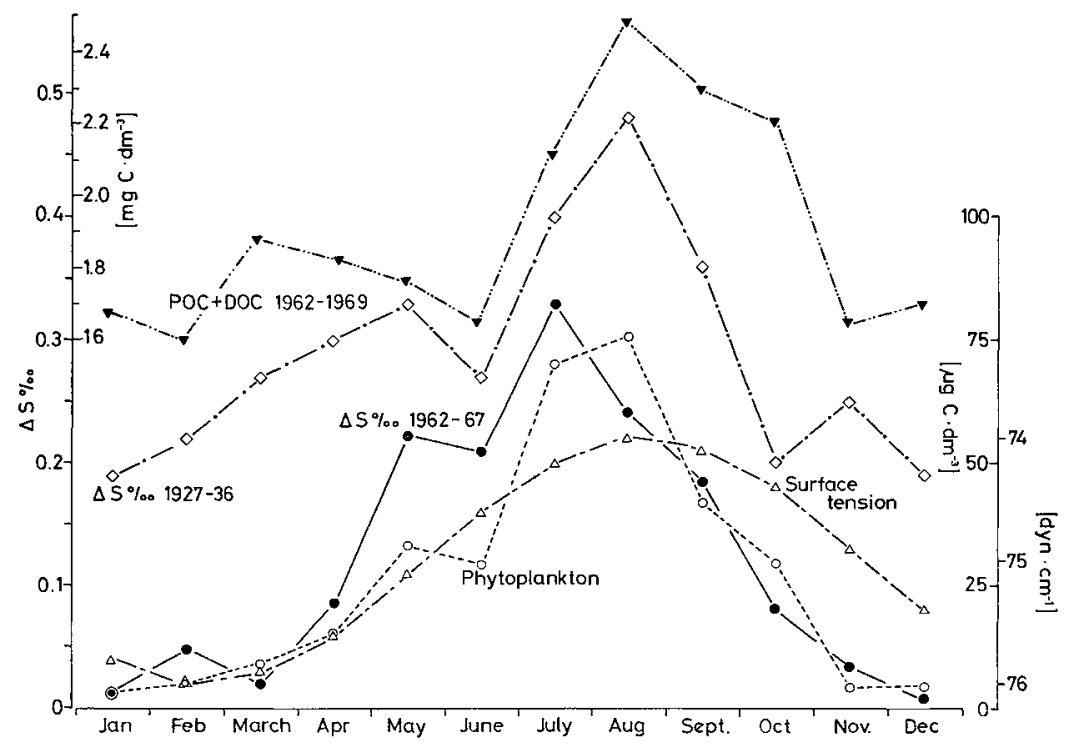

Fig. 6. Helgoland Roads: monthly mean values: total organic carbon by permanganate oxidation (org. C) $1962 / 69\left[\mathrm{mg} \mathrm{C} \cdot \mathrm{dm}^{-3}\right]_{i} \Delta \mathrm{S} \%$ o (hydrometer value - true value) $1927 / 36$ (Goedecke, 1956); $\Delta \mathrm{S} \%$ o, phytoplankton carbon $\left[\mu \mathrm{g} \mathrm{C} \cdot \mathrm{dm}^{-3}\right]$ and surface tension $1962 / 67$

ved) determined by means of a simple permanganate oxidation (Gillbricht, 1957) show parallel values. This is the same with surface tension indicating surface-active organic compounds and measured indirectly by deviations of hydrometer readings $(\Delta \mathrm{S} \% \mathrm{o})$. These deviations, first observed and investigated by Nansen (1902a, b), cannot be explained by fluctuations of the surface tension of pure sea water and must therefore indicate biological activities. The reasons for the abnormal situation observed during this investigation are not yet clear. It may be due to the fact that the investigation was carried out in an old water body of the central North Sea which is rich in organic carbon (Gillbricht, 1957). The transformation from dissolved matter into particulate matter may have been influenced (catalytically?) by the material newly built up during the spring bloom. These new substances are only small in quantity compared with the old organic compounds. It is therefore not possible to correct the curves given in Figure 5 with respect to the new material. If we assume the daily release of dissolved organic matter to be a function of the particulate phytoplankton production and this production to amount to $200 \%$ of the phytoplankton stock, then the daily decrease of the dissolved matter 
should be ca. $1.5(0.3$ to 2.5$) \%$ greater than that presented in Figure 5. This value is not much different from that given by the graph.

The observations discussed here are more or less in agreement with the results of other authors (e.g. Riley, 1970; Kranck, 1980). Nevertheless, various questions remain unanswered, especially as to whether the transformation of dissolved matter into particulate matter in situ is an exceptional event or a normal situation which has, for different reasons, remained hitherto undetected. More detailed investigations are necessary in this field before further insight into these complex dynamic processes can be obtained

Acknowledgments. The Deutsche Forschungsgemeinschaft supported these investigations by grants and especially by making the R. V. "Meteor" available. We thank many persons for having taken the samples for us. The crew of the motor boat "Ellenbogen" (Mr. J. Herzog and Mr. W. Krüss) carried out the hydrometer measurements. Mrs. B. Freier assisted in counting the phytoplankton, making the calculations and preparing the graphs. Mr. J. Marschall made the drawings and Mrs. C. Berger corrected the English text.

\section{LITERATURE CITED}

Anderson, G. C. \& Zeutschel, R. P., 1970. Release of dissolved organic matter by marine phytoplankton in coastal and offshore areas of the Northeast Pacific Ocean. - Limnol. Oceanogr. 15, 402-407.

Brockmann, U., Ittekkot, V., Kattner, G., Eberlein, K. \& Hammer, K. D., 1982. Release of dissolved organic substances in the course of phytoplankton blooms. In: North Sea dynamics. Ed. by J. Sündermann \& W. Lenz. Springer, Berlin (in press).

Choi, C. I.; 1972. Primary production and release of dissolved organic carbon from phytoplankton in the western North Atlantic Ocean. - Deep-Sea Res. 19, 731-735.

Duursma, E. K., 1963. The production of dissolved organic matter in the sea, as related to the primary gross production of organic matter. - Neth. J. Sea. Res. 2, 85-94.

Duursma, E. K., 1965. Dissolved organic matter in surface water as a parameter for primary production. - Memorie Ist. ital. Idrobiol. (Suppl.) 18, 161-163.

Fogg, G. E., Nalewajko, C. \& Watt, W. D., 1965. Extracellular products of phytoplankton photosynthesis. - Proc. R. Soc. (B) 162, 517-534.

Gillbricht, M., 1952. Untersuchungen zur Produktionsbiologie des Planktons in der Kieler Bucht I. Kieler Meeresforsch. 8, 173-191.

Gillbricht, M., 1957. Ein Verfahren zum oxydativen Nachweis von organischer Substanz im Seewasser. - Helogländer wiss. Meeresunters. 6, 76-83.

Gillbricht, M., 1959. Das Phytoplankton im nördlichen Nordatlantischen Ozean im Spätwinter und Spätsommer 1958. - Dt. hydrogr. Z. (B) Erg. H. 3, 90-93.

Gillbricht, M., 1962. Über das Auszählen von Planktonschöpfproben. - Helgoländer wiss. Meeresunters. 8, 203-218.

Gillbricht, M, 1977. Phytoplankton distribution in the upwelling area off NW Africa.-Helgoländer wiss. Meeresunters. 29, 417-438.

Goedecke, E., 1956. Über das Verhalten des Oberflächensalzgehaltes in der Deutschen Bucht während der Jahre 1873-1944 in Verbindung mit langjährigen Salzgehaltsreihen der südlichen Nordsee. - Ber. dt. wiss. Kommn Meeresforsch. 14, 109-146.

Hühnerfuss, H., Walter, W. \& Kruspe, G., 1977. On the variability of surface tension with mean wind speed. $-J$. phys. Oceanogr. 7, 567-571.

Kalle, K., 1968. Das Problem der gelösten organischen Substanz, erläutert an den Verhältnissen im Meerwasser. - Mitt. int. Verein. theor. angew. Limnol. 14, 72-82.

Kranck, K., 1980. Variability of particulate matter in a small coastal inlet. - Can. J. Fish. aquat. Sci. 37, 1209-1215. 
Laane, R. W. P. M., 1980. Conservative behaviour of dissolved organic carbon in the Ems-Dollart estuary and the western Wadden Sea. - Neth. J. Sea. Res. 14, 192-199.

Lenz, J., 1977. On detritus as a food source for pelagic filter-feeders. - Mar. Biol. 41, 39-48.

Lohmann, H., 1908. Untersuchungen zur Feststellung des vollständigen Gehaltes des Meeres an Plankton. - Wiss. Meeresunters. (Abt. Kiel) 10, 129-370.

Menzel, D. W. \& Vaccaro, R. F., 1964. The measurement of dissolved organic and particulate carbon in seawater. - Limnol. Oceanogr. 9, 138-142.

Nansen, F., 1902a. The oceanography of the North Polar Basin. - Scient. Results Norw. N. polar. Exped. 3 (9), 1-427.

Nansen, F., 1902b. On hydrometers and the surface tension of liquids. - Scient. Results Norw. N. polar Exped. $3(10), 1-87$.

Neihof, R. \& Loeb, G., 1974. Dissolved organic matter in seawater and the electric charge of immersed surfaces. - J. mar. Res. 32, 5-12.

Puitter, A., 1909. Die Ernährung der Wassertiere und der Stoffhaushalt der Gewässer. Fischer, Jena, $168 \mathrm{pp}$.

Raben, E., 1910. Ist organisch gebundener Kohlenstoff in nennenswerter Menge im Meerwasser gelöst vorhanden? - Wiss. Meeresunters. (Abt. Kiel) 11, 109-117.

Ramsey, W. L., 1962. Dissolved oxygen in shallow near-shore water and its relation to possible bubble formation. - Limnol. Oceanogr. 7, 453-461.

Riley, G. A., 1970. Particulate and organic matter in sea water. - Adv. mar. Biol. 8, 1-118.

Schreiber, E., 1927. Die Reinkultur von marinem Phytoplankton und deren Bedeutung für die Erforschung der Produktionsfähigkeit des Meerwassers. - Wiss. Meeresunters. (Abt. Helgoland) $16(10), 1-35$.

Tsujita, T., 1953. A preliminary study on naturally occurring suspended organic matter in waters adjacent to Japan. - J. oceanogr. Soc. Japan 8, 113-126.

Wandschneider, K., 1979. Vertical distribution of phytoplankton during investigations of a natural surface film. - Mar. Biol. 52, 105-111.

Wangersky, P. J., 1978. Production of dissolved organic matter. In: Marine ecology. Ed. by O. Kinne. Wiley, Chichester, 4, 115-220.

Wangersky, P. J., 1981: The determination of dissolved organic carbon in sea water. - Trends analyt. Chem. 1, 28-30.

ZoBell, C. E., 1933. Photochemical nitrification in sea water. - Science, N. Y. 77, 27-28.

ZoBell, C. E. \& Anderson, D. Q., 1936. Observations on the multiplication of bacteria in different volumes of strored sea water and the influence of oxygen tension and solid surfaces. - Biol. Bull. mar, biol. Lab., Woods Hole 71, 324-342. 